\title{
PERFIL E TRAJETÓRIAS DE ESTUDANTES EM CURSOS DE PÓS-GRADUAÇÃO STRICTO SENSU NO MERCOSUL: "É PRESENCIAL, NÉ?"
}

\author{
PROFILE AND TRAJECTORIES OF STUDENTS IN STRICTO \\ SENSU POSTGRADUATE COURSES IN MERCOSUR: \\ "IT'S FACE-TO-FACE, RIGHT?"
}

\author{
PERFIL Y TRAYECTORIAS DE ESTUDIANTES EN \\ CURSOS DE POSGRADO STRICTO SENSU EN EL \\ MERCOSUR ¿ES PRESENCIAL?
}

Priscilla Campos de CASTro ${ }^{\mathrm{I}}$

CARLOS LOPES ${ }^{\mathrm{I}}$

${ }^{\text {I } U n i v e r s i d a d e ~ d e ~ B r a s i ́ l i a ~(U n B), ~ B r a s i ́ l i a / D F, ~ B r a s i l ~}$

Resumo O artigo tem por objetivo identificar e analisar o perfil de oito brasileiros que cursaram a pós-graduação stricto sensu em dois países do Mercosul - Paraguai e Argentina -, suas percepções sobre a modalidade do curso e a questão do reconhecimento do diploma. O artigo tem como referencial os conceitos de trajetórias (MONTAGNER, 2007) e de capital cultural e econômico (BOURDIEU, 2008). A pesquisa qualitativa, do tipo descritiva e exploratória, adota a metodologia da reflexividade reflexa (BOURDIEU, 2008). Todos os pós-graduandos são pessoas estabelecidas profissionalmente. Em sua maioria, maduras pelo enfrentamento de obstáculos e dificuldades em suas trajetórias; faixa etária superior à daqueles em cursos presenciais no Brasil; pais com baixo capital cultural e em profissões julgadas de menor prestígio social; e cinco dos oito entrevistados nunca tentaram seleção no Brasil. A modalidade do curso se configura como semipresencial. A escolha do curso se deu pela modalidade flexível, pelo valor, pela possibilidade de conciliar os estudos com as férias e, implicitamente, pela seleção com menor rigor. Os estudantes se esforçam para possuir o capital cultural institucionalizado e reconhecer o diploma. Nenhum teve o reconhecimento do mestrado no Brasil. Esses estudantes não herdaram da família o capital cultural e econômico necessário ao investimento em pós-graduação no exterior, mas, ao longo da sua condição de trabalho, com o passar do tempo, puderam constituir um capital para o investimento.

Palavras-chave: Estudantes; Trajetórias; Capital cultural; Pós-graduação; MerCOSUL. 
ABSTRaCr The article aims to identify and analyze the profile of eight Brazilians who attended stricto sensu postgraduate courses in two Mercosur countries - Paraguay and Argentina -, perceptions about the course modality and the issue of diploma recognition. The article is based on the concepts of trajectories (MONTAGNER, 2007) and cultural and economic capital (BOURDIEU, 2008). The qualitative research, of the descriptive and exploratory type, adopts the reflexive reflexivity methodology (BOURDIEU, 2008). All postgraduate students are professionally established people. Most of them, mature due to facing obstacles and difficulties in their trajectories; older age group than those in classroom courses in Brazil; parents with low cultural capital, in professions judged to be of lesser social prestige and that five of the eight respondents never tried selection in Brazil. The course modality is configured as semi-presential. The choice of the course was due to its flexibility, price of investment, the possibility to combine studies with holidays and, implicitly, by selection with less rigor. Students strive to own institutionalized cultural capital and recognize the diploma. None had the recognition of the master's degree in Brazil. These students did not inherit from their family the cultural and economic capital necessary for investment in postgraduate studies abroad, but, throughout their working conditions and the passage of time, they were able to constitute a capital for investment.

Keywords: Students; Trajectories; Cultural capital; Postgraduate; Mercosur.

RESUMEN El artículo tiene por objetivo identificar y analizar el perfil de ocho estudiantes brasileños que cursaron posgrados stricto sensu en dos países del Mercosur - Paraguay y Argentina -, las percepciones sobre la modalidad del curso y el reconocimiento del diploma. El artículo se basa en los conceptos de trayectorias (MONTAGNER, 2007) y capital cultural y económico (BOURDIEU, 2008). La investigación cualitativa, de tipo descriptivo y exploratorio, se guió por el enfoque metodológico de la reflexividad refleja. (BOURDIEU, 2008). Todos ellos son personas ya profesionales. En su mayoría maduras pelos obstáculos dificultades en sus trayectorias; rango de edad superior a la de aquellos en cursos presenciales en Brasil; padres con bajo capital cultural y en profesiones juzgadas de menor prestigio social y que cinco de los ocho encuestados nunca intentó selección en Brasil. La modalidad de curso constituye un escenario educativo semipresencial. La elección del curso se dio por la modalidad flexible, valor del curso, de conciliar los estudios con las vacaciones e, implícitamente, por selección con menos rigor. Los estudiantes se esfuerzan por poseer un capital cultural institucionalizado y reconocer el diploma. Ninguno tuvo el reconocimiento de diploma en Brasil. Esos estudiantes no heredaron de la familia el capital cultural y económico necesario a la inversión en posgrado en el exterior, pero, a lo largo de su condición de trabajo y con el paso del tiempo, pudieron constituir un capital para la inversión.

Palabras Clave: Estudiantes; Trayectorias; Capital cultural; Posgrado; Mercosur.

\section{INTRODUÇÃo}

Com o desenvolvimento do ensino superior no Brasil, sobretudo a partir da sua oferta em massa por instituições privadas, a demanda de formação se alastrou também para cursos de formação continuada, tanto lato sensu quanto stricto sensu. 
A Coordenação de Aperfeiçoamento de Pessoal de Nível Superior (Capes) (AVALIAÇÃO..., 2017) apresenta dados sobre o crescimento da pós-graduação brasileira e faz referência ao fato de ainda existirem regiões tradicionalmente defasadas nesta oferta. Nesse sentido, os países vizinhos perceberam essa demanda no mercado brasileiro e adaptaram sua oferta ao público nacional. Porém, um novo desafio se apresenta após o término do curso, que é o reconhecimento do diploma do pós-graduando no Brasil, pois, sem ele, o diploma não surtirá os efeitos legais.

Cabe-nos esclarecer duas nomenclaturas usualmente misturadas: revalidação versus reconhecimento. Conforme a legislação em vigor, revalidação é um processo que objetiva atribuir plenos efeitos a um diploma de graduação emitido fora do Brasil. Já o reconhecimento é voltado para diplomas de pós-graduação stricto sensu (mestrado e doutorado) emitidos por instituições não brasileiras.

Existe uma enorme concentração de programas de pós-graduação stricto sensu na modalidade presencial, com oferta predominante durante o período diurno, no Sul e no Sudeste do país. Logo, o estudante-trabalhador que deseja obter o diploma deve se submeter a essas caraterísticas, assumindo os desafios e as dificuldades de conciliar a sua vida laboral com as especificidades e implicações de um curso presencial de mestrado e doutorado no Brasil.

Dados sobre o quantitativo de solicitações de reconhecimento de diplomas de mestrado e doutorado cursados em instituições educacionais localizada em países do Mercado Comum do Sul (Mercosul) ${ }^{1}$ e o número daqueles efetivamente concedidos demonstram a preponderância do indeferimento dos processos. Os motivos recorrentes de indeferimento (UNB, 2020) dizem respeito à modalidade do curso ministrado. Assim, não são reconhecidas as categorias de cursos de pós-graduação stricto sensu: a distância, semipresencial, de forma sazonal ou intensiva. Ademais, outro fator da negativa refere-se à baixa reputação acadêmica da instituição em que se deu o curso.

Diante do exposto, este artigo tem por objetivo identificar e analisar o perfil dos pós-graduandos brasileiros que optaram por cursar a pós-graduação stricto sensu em dois países do Mercosul e as suas percepções sobre a modalidade de formação e a questão do reconhecimento do curso, considerando o recorte interpretativo pelos conceitos de trajetórias e pela relação entre o capital cultural e o econômico. ${ }^{2}$ Também foram incluídas no levantamento do perfil dos pós-graduandos as informações sobre as suas famílias.

Vale esclarecer que, ao tempo em que concluíamos a pesquisa de campo, foi instituída a Portaria Capes no 90, de 24 de abril de 2019 (CAPES, 2019a), regulamentando a pós-graduação stricto sensu na modalidade educacional a distância (EaD) para programas acadêmicos e profissionais. Diante desse fato, tal regulamentação não foi o nosso ponto de partida ou mesmo o objeto central das nossas discussões sobre o processo de reconhecimento de diplomas de cursos a distância de instituições estrangeiras. Todavia, levantaremos algumas problematizações sobre tal ponto e sinalizaremos algumas tendências. Ao contrário dos cursos de graduação brasileiros, que há algum tempo contam com prescrições

I O Mercosul é formado pelos seguintes países: Brasil, Paraguai, Argentina e Uruguai.

2 Este texto, base da pesquisa de Castro (2019), foi adaptado e ampliado para o formato de artigo. A pesquisa foi realizada no âmbito da linha de investigação Educação, Tecnologias e Comunicação (ETEC), no Programa de Pós-Graduação em Educação da Universidade de Brasília (UnB), antes da pandemia de Covid-19. 
legais e normativas para regular a oferta a distância e semipresencial, na pós-graduação stricto sensu a regulamentação é algo recente, iniciada em 2019.

O artigo está organizado da seguinte maneira: a primeira seção apresenta o quadro conceitual e metodológico da pesquisa, destacando a reflexão sobre a educação semipresencial, presencial e $\mathrm{EaD}$, com recorte para a pós-graduação stricto sensu, além das concepções de trajetórias (MONTAGNER, 2007) e de capital cultural e econômico (BOURDIEU, 2002); a abordagem metodológica da reflexividade reflexa (BOURDIEU, 2008); os sujeitos da pesquisa; os instrumentos utilizados para a coleta de dados e informações; e o modo como foram analisados. Na segunda seção, apresentamos e discutimos os resultados da investigação com base nas unidades de análise: a) perfil dos pós-graduandos e b) a modalidade do curso e a questão do reconhecimento do diploma. Por fim, apresentamos as nossas conclusões.

\section{QuAdro CONCEITUAL E METOdológico Da PESQUisa}

\section{Educação semipresencial, presencial e EAD}

A educação semipresencial busca aglutinar as diferentes facetas da educação presencial e da EaD. Desse modo, uma parte das atividades é realizada de forma presencial, e a outra em espaços virtuais, permitindo assim que, mesmo em uma situação de formação predominantemente presencial, o aluno possa desenvolver sua autonomia e controlar a gestão do tempo e do espaço, como potencializa a EaD. É evidente que tem se tornado cada vez mais complexo conceituar de modo pontual o que é educação a distância, presencial ou semipresencial, pois os impactos da tecnologia e das formas de comunicação e expressão não são limitados por conceitos ou legislações. A fronteira que separa as diferentes situações educativas (presencial, a distância e semipresencial) é permeável e possui pontos de encontro e divergências. Assim como na educação presencial, na situação educativa semipresencial e na modalidade $\mathrm{EaD}$, há diferentes modelos pedagógicos e de aprendizagem mediados por tecnologias da informação e comunicação.

$\mathrm{Na}$ relação entre as modalidades semipresencial e EaD, é possível encontrar aspectos convergentes em determinados modelos pedagógicos, a exemplo do suporte de recursos e linguagens tecnológicas digitais, incluindo a aplicação da inteligência artificial; a mediação pedagógica humana; os espaços e tempos, por vezes diferenciados, nos quais se situam os diferentes sujeitos ou objetos da aprendizagem. Na organização pedagógica e curricular da semipresencialidade, as relações cotidianas no espaço da instituição escolar, face a face, continuam sendo a base dos processos de ensino-aprendizagem, ao passo que a outra parte das atividades é desenvolvida a distância.

A Portaria Capes $n^{\circ}$ 90/ 2019, ao tratar da regulamentação para a oferta de cursos de pós-graduação stricto sensu na modalidade $\mathrm{EaD}$, em programas acadêmicos e profissionais, ${ }^{3}$ prescreve que os estudantes deverão cumprir atividades presenciais tais como: estágio obrigatório, seminários integrativos, práticas profissionais e avaliações presenciais,

3 No momento da concepção, do planejamento e da operacionalização das entrevistas, a Portaria Capes n ${ }^{\circ} 90 /$ 2019 ainda não havia sido instituída. Dessa forma, tal tópico não foi contemplado no roteiro das entrevistas nem fez parte da base para a análise dos dados coletados.- 
entre outras, a serem definidas nos projetos político-pedagógicos dos cursos e nos regulamentos das instituições de ensino. Segundo o documento, somente as instituições de ensino superior que estiverem credenciadas no Ministério da Educação (MEC) poderão ofertar cursos a distância. Além disso, a instituição deverá possuir o Índice Geral de Cursos (IGC), indicador utilizado pelo MEC para avaliar a qualidade das Instituições de Ensino Superior (IES), igual ou superior a 4. Além do mais, a Capes frisa que "[...] a oferta de disciplinas esparsas a distância não caracteriza, per se, os cursos como a distância" (CAPES, 2019b). Portanto, com tal ênfase, singulariza-se a distinção entre os cursos de pós-graduação stricto sensu a distância e semipresencial (ou híbrido). No caso da graduação presencial, diferentemente da pós-graduação stricto sensu presencial, já há regulamentação que especifica o percentual da carga horária a distância do curso, que pode ser de até 40\% (CAPES, 2019a).

\section{O conceito de trajetórias e de capital cultural e econômico}

Nosso recorte enfatiza o conceito de trajetória dos sujeitos e sua relação com o processo de cursar uma pós-graduação em países do Mercosul. Por conseguinte, alinhamo-nos com uma perspectiva de análise em que o "sujeito social é colocado como o centro e a chave das análises” (MONTAGNER, 2007, p. 241). Entretanto, as análises não podem esgotar tudo quanto envolva as escolhas dos estudantes, mas apenas se concentrar em conhecimentos parciais que nos permitam desvendar suas trajetórias. Compreender tais trajetórias a partir dos relatos não implica, como dito anteriormente, esgotar o assunto ou dar a palavra final, pois "[...] o conhecimento do vivido não significa necessariamente a compreensão do real" (MONTAGNER, 2007, p. 248), sob pena de incorrermos no que Bourdieu (1999) chamou da ilusão da transparência.

Segundo Montagner (2007), a dinâmica da regularidade do social é o que guia a compreensão do conceito de campo. ${ }^{4}$ As condições de reprodução do campo já estão contidas nele mesmo, tais como os meios de formação de novos integrantes (escolas, universidades, escola bíblica dominical), as instâncias de consagração (o que é valorizado/incentivado ou não) e as instâncias e os modos de seleção de novos integrantes (concursos, formas de avaliação).

Assim, para identificar a posição do estudante no campo, utiliza-se como indicador o capital. Temos outro conceito importante na análise sociológica de Bourdieu, que toma emprestado o conceito de capital econômico para espraiá-lo a outros domínios, levando a uma “economia geral das práticas” (LEBARON, 2017, p. 101), na perspectiva do patrimônio social. O capital é um recurso em estoque que o indivíduo possui (CATANI, 2017). Esse recurso pode ser transmitido, herdado ou até mesmo transformado.

Bourdieu trata de quatro tipos de capital: o capital econômico (bens, dinheiro, conforto), o capital cultural (falar outras línguas, diplomas), o capital social (liderança, família, comunidade) e o capital simbólico (celebridade, honestidade, beleza, cor da pele). De acordo com Bourdieu (2002, p. 197), “[...] os diplomas escolares são para o capital cultural o que a moeda é para o Capital econômico".

4 No artigo, fazemos menção a outros conceitos de Bourdieu, como os de campo, capital social e habitus, porém não temos a pretensão de aprofundá-los na correlação com os dados das entrevistas. Esses conceitos servem para situar o pensamento de Bourdieu de uma forma geral. Assim, optamos pela perspectiva heurística de intepretação, com o uso pontual dos conceitos de capital cultural e econômico em uma pesquisa com característica descritiva e exploratória. 
Assim como em uma economia pré-capitalista onde uma garantia vale o que vale o fiador, o diploma vale fora do mercado escolar o que seu detentor vale econômica e socialmente, sendo que o rendimento do capital escolar (forma transformada do capital cultural) depende do capital econômico e social que pode ser utilizado em sua valorização. (BOURDIEU, 2007, p. 333).

Bourdieu (1982, p. 101) define o capital social como o "[...] agregado de recursos, reais ou potenciais, ligados à posse de uma rede durável de relações, mais ou menos institucionalizadas, de reconhecimento mútuo". Assim, de acordo com o autor, o capital social é constituído a partir dos vínculos estabelecidos por indivíduos pertencentes a um determinado grupo social, e o que caracteriza esse tipo de capital são relações sociais de amizade, família, vizinhança, trabalho, clubes, igrejas, escola, comunidades e outros espaços que podem gerar benefícios materiais ou simbólicos (SAINT MARTIN, 2017).

Para Bourdieu, a trajetória social "[...] se refere originalmente à evolução ao longo do tempo de propriedades, tais como o volume e a estrutura do capital do grupo analisado" (apud BRITO, 2017, p. 354).

[...] o habitus seria um conjunto de esquemas implantados desde a primeira educação familiar, e constantemente repostos e reatualizados ao longo da trajetória social restante, que demarcam os limites à consciência possível de ser mobilizada pelos grupos e/ou classes, sendo assim responsáveis, em última instância, pelo campo de sentido em que operam as relações de força. (BOURDIEU, 2007, p. 44).

Essas diferentes posições ocupadas dentro de um campo, de acordo com o capital acumulado, dão origem às representações subjetivas sobre a posição objetivamente ocupada. Assim, para compreender a trajetória, é preciso " [...] construir anteriormente os estados sucessivos do campo onde ela se passa, o conjunto das relações objetivas que ligam o agente em questão ao conjunto dos outros agentes presentes no mesmo campo e que se defrontam com o mesmo espaço possível" (BRITO, 2017, p. 355). Dessa forma, é a partir da trajetória social do agente que se poderá compreender suas práticas. Dentro de um campo, a trajetória, em regra, é limitada pelo espaço do possível (probabilidade), mesmo que existam casos (efeitos de trajetória) em que "[...] agentes dotados das mesmas propriedades e ocupando a mesma posição social podem ter uma trajetória social diferente da trajetória modal (estatística) de seu grupo" (BRITO, 2017), ou seja, uma trajetória individual.

\section{A abordagem da reflexividade reflexa, sujeitos da pesquisa, instrumen- tos de coleta e análise}

O tipo de investigação realizada no presente artigo é de natureza qualitativa, definida como do tipo descritiva e exploratória (TRIVIÑOS, 1987). A pesquisa foi orientada pela abordagem da reflexividade reflexa (BOURDIEU, 2008). Nessa abordagem, deve-se ultrapassar os pressupostos próprios às técnicas de pesquisa e preocupar-se com as condições sociais das práticas objetivamente postas. Nesse sentido, Bourdieu (2008, p. 694) afirma que: 
Só a reflexividade, que é sinônimo de método, mas uma reflexividade reflexa, baseada num trabalho, num olho sociológico permite perceber e controlar no campo, na própria condução da pesquisa os efeitos da estrutura social na qual ela se realiza.

Trata-se, portanto, de um olhar crítico e sensível por parte do pesquisador, que foge do senso comum e da neutralidade com os sujeitos e com o contexto da pesquisa, visando reduzir a violência simbólica. Assim, o pesquisador busca ultrapassar uma perspectiva positivista de pesquisa, em que o fato social pode ser isolado e trabalhado em laboratório, típico das ciências naturais, e passa a refletir sobre o contexto, as regras presentes, os capitais necessários e seu próprio posicionamento dentro do campo. Logo, "[...] na realidade, o sociólogo (pesquisador) não é um ser desencarnado: é um sujeito social que se caracteriza por uma pertença social, um sexo, uma idade, mas também por preferências e aversões" (JOURDAIN; NAULIN, 2017, p. 39). Dessa forma, quando do processo de pesquisa, o próprio pesquisador já traz consigo um conjunto de noções prévias a respeito do seu objeto de pesquisa.

Segundo o autor, a reflexividade reflexa "[...] pode ser capaz de permitir um trabalho científico que consiga controlar o campo, desde a escolha dos temas, a escolha dos entrevistados e a própria condução da entrevista no que se refere aos efeitos da estrutura social na qual o estudo se insere" (BOURDIEU, 2008, p. 694).

Para a coleta de dados, utilizou-se como instrumento a entrevista semiestruturada. ${ }^{5}$ Inicialmente, para chegar aos sujeitos e dar viabilidade à pesquisa, adotamos a estratégia da aproximação geográfica dos pesquisadores em relação aos possíveis entrevistados;_selecionamos uma instituição pública educacional cujos servidores, por informações que nos foram passadas por colegas, tinham cursado pós-graduação stricto sensu em países do Mercosul, principalmente no Paraguai. A partir desses contatos, buscamos a indicação de novos participantes, e assim sucessivamente. Foram realizados três contatos com trabalhadores dessa instituição educacional. Todos tinham realizado o curso no Paraguai. Apenas um dos convidados se prontificou a participar da pesquisa. Conjecturamos que a rejeição dos demais convidados se deveu ao fato de que, na IES em que trabalham, tem predominado o não reconhecimento de títulos oriundos do Paraguai. Portanto, havia certa desconfiança por parte daqueles que pretendiam se posicionar no campo educacional como pós-graduados (mestres), ainda sem o título reconhecido no Brasil (os entrevistados), para com aqueles já posicionados como pesquisadores de uma instituição com programa stricto sensu presencial reconhecido. Como já frisado, a estratégia para alcançar outros pós-graduandos que fizeram cursos em países do Mercosul foi solicitar a cada entrevistado que indicasse colegas de formação de outras regiões do país. Diante dessa circunstância, estabelecemos o contato pela internet com os pós-graduandos indicados. Em alguns casos, não obtivemos resposta dos contatos para adesão à entrevista; em outros, houve pronta disponibilidade. Seguindo esse critério, chegamos ao total de oito entrevistados, oriundos das seguintes unidades da federação: Distrito Federal, Tocantins, Rio de Janeiro, Minas Gerais e Maranhão.

Para a análise dos dados, estabelecemos as seguintes unidades analíticas: a) o perfil dos pós-graduandos; e b) a modalidade do curso e a questão do reconhecimento do diplo-

Todos os entrevistados assinaram o Termo de Consentimento Livre e Esclarecido (TCLE). 
ma. Correlacionamos cada unidade analítica às fontes de triangulação dos dados (TRIVIÑOS, 1987), quais sejam: a) entrevistas com os sujeitos e as percepções dos pesquisadores a partir do quadro conceitual, da literatura e da abordagem metodológica de pesquisa; $b$ ) documentos legais e dados quantitativos, quando necessários; c) referências à desigualdade estrutural na oferta da pós-graduação stricto sensu.-

\section{APRESENTAÇÃo e discussão dos ReSUltados}

\section{Perfil dos pós-graduandos}

Ao apresentar os dados e discuti-los, optamos por resguardar a identidade dos sujeitos da pesquisa. Assim, utilizamos nomes fictícios: Dalva, Laura, Vivian, Tatiana, Davi, Fernando, Lucas e Jorge. Sete dos oito entrevistados estudaram no Paraguai, e um na Argentina. ${ }^{6}$ Todos os oito entrevistados são ex-estudantes do curso de mestrado, entre os quais um tem título de doutor. No momento da entrevista, cinco estavam cursando o doutorado no Paraguai.

Quanto à formação stricto sensu, os estudantes eram egressos dos cursos de Administração, Marketing, Educação, Saúde e Direito. Dos oito participantes, seis têm idade superior a 50 anos, que variam entre 52 a 62 anos. De forma geral, notamos algumas similaridades entre os perfis dos estudantes, com exceção, em termos de idade, dos entrevistados Tatiana (28 anos) e Lucas (41 anos). A idade dos entrevistados nos chamou atenção, pois a maioria possui faixa etária superior a 50 anos, fato bem diferente do perfil de estudantes que realizam a pós-graduação stricto sensu no Brasil. Segundo Schwartzman (2010), no Brasil, a idade média dos estudantes nas modalidades de pós-graduação lato sensu e stricto sensu é de 34 anos e, geralmente, há uma rota direta da graduação para a pós-graduação. Colombo (2018), citando dados da Capes (2017) e do Instituto Nacional de Estudos e Pesquisas Educacionais Anísio Teixeira (INEP, 2017), demonstra que o estudante da pós-graduação stricto sensu é majoritariamente recém-egresso da universidade, sendo que $45 \%$ dos estudantes do mestrado concluíram seu curso no mesmo ano ou no anterior, e apenas $25 \%$ ingressaram após três anos. Já os do doutorado concluíram a graduação no terceiro ano anterior ao ingresso e aproximadamente dois terços dos ingressantes concluíram a graduação até quatro anos antes (COLOMBO, 2018). Portanto, há uma grande diferença etária entre os estudantes recém-egressos da universidade que entraram na pós-graduação stricto sensu no Brasil e aqueles que se matricularam em cursos no Mercosul; no caso em análise, no Paraguai e na Argentina.

Ao analisar o estado civil, identificamos que quatro participantes são casados, uma é viúva, uma divorciada e dois são solteiros. Dos oito participantes, cinco possuem entre dois e quatro filhos. A idade dos filhos varia de 16 a 32 anos de idade. E o tamanho da família, de três a onze irmãos.

No que tange à renda familiar, cinco entrevistados afirmaram ter renda familiar superior a quatro salários-mínimos, ao passo que os outros três disseram possuir renda inferior a este patamar.

6 Mesmo com a predominância do Paraguai como o destino de sete pós-graduandos, com exceção de um participante, que se formou na Argentina, utilizaremos no texto o plural 'países do Mercosul'. Não conseguimos entrevistar mais pós-graduandos formados na Argentina, nem os que optaram pelo Uruguai - ambos países integrantes do Mercosul -, porque não obtivemos resposta aos contatos feitos por e-mail, pesando a indicação daqueles que estudaram no Paraguai. 
Esses dados prévios nos forneceram alguns elementos de análise, sobretudo quando cruzados com outras informações do perfil. Por exemplo, quanto à profissão, todos são servidores públicos. Atualmente, os entrevistados exercem as seguintes profissões: técnico em assuntos educacionais, enfermeira municipal, aposentada de uma empresa pública federal, agente social e técnica judiciária; três são professores, dentre os quais um é docente de uma universidade federal. Os outros dois professores atuam na rede municipal. Para complementar a renda, os dois professores da rede municipal trabalham em IES privadas. Esses aspectos demonstram que esses estudantes tiveram duas condições que, em alguns casos, de forma associada, favoreceram sua saída do Brasil: a primeira é a condição de servidores públicos, que, sob o manto da estabilidade, aponta para certa tranquilidade em termos de emprego, com oportunidades de licença-capacitação e gratificação por titulação. A segunda condição é o fato de se tratar de indivíduos já maduros, isto é, com os filhos criados, o que lhes propiciou a retomada dos estudos de forma mais tranquila.

Outro dado importante do perfil dos estudantes diz respeito ao local em que nasceram. Dos oito, sete residem no interior dos seguintes estados: Ceará, Goiás, Minas Gerais, Maranhão, Pará e Paraná. Apenas uma estudante é nascida em Brasília, DF.

No que diz respeito à origem escolar, quanto ao ensino fundamental e ao ensino médio, os entrevistados são provenientes, majoritariamente, de instituições públicas; apenas dois são originários de escolas particulares. Quanto ao ensino superior, seis afirmaram ter realizado o curso em instituições privadas. Quando questionados a respeito da formação no ensino superior, os entrevistados apresentaram as seguintes respostas: licenciatura em Letras, Artes Plásticas, Música, Pedagogia, Secretariado Executivo, Enfermagem, Recursos Humanos, Direito e Filosofia. Dos oito, três possuem duas graduações.

Com relação ao idioma, capital cultural fundamental para o desenvolvimento do curso de pós-graduação em outros países do Mercosul, nos quais o espanhol é a língua predominante, três estudantes afirmaram não falar nenhuma língua estrangeira. Quatro declararam possuir habilidades em espanhol. Destes, três também possuem conhecimentos da língua inglesa; e dois, além de espanhol e do inglês, possuem conhecimentos em outros idiomas.

Laura, quando questionada sobre seus conhecimentos em língua estrangeira, afirmou ser poliglota: fala inglês, um pouco de italiano e espanhol. Já Fernando afirmou ter conhecimentos da língua inglesa e se virar bem com o espanhol; como teve acesso à escola de música, onde se tornou cantor de ópera, disse que, para ser tenor, é obrigado saber pronunciar pelo menos cinco idiomas.

De famílias desprovidas de recursos financeiros, alguns dos entrevistados afirmaram que começaram a trabalhar muito jovens para auxiliar os pais, conforme os relatos abaixo:

[...] viemos de uma família muito pobre. Abaixo do que se espera. Eu tive que trabalhar como vendedor ambulante, vendedor de banana frita. Nas escolas, eu já trabalhei como vigia e como merendeiro. (Lucas).

[...] A primeira coisa com que eu trabalhei foi anodização de esquadrilha metálica de alumínio, quando eu tinha 14 anos, e trabalhei para ajudar o meu pai. Já trabalhei consertando rádio e televisão certa época da minha vida e também trabalhei com música - e continuo, inclusive, trabalhando atualmente. (Fernando). [...] Eu comecei a trabalhar muito cedo, com 18 anos. Eu fui ser assistente como todo mundo, auxiliar nisso e naquilo. (Vivian). 
Assim, percebe-se que as dificuldades econômicas e familiares exerceram forte influência para que esses entrevistados começassem a trabalhar precocemente. Quando correlacionamos a escolaridade dos entrevistados à dos pais, identificamos que o nível da formação escolar destes últimos é baixo em relação ao dos primeiros. Apenas a mãe de uma entrevistada possui graduação em Pedagogia.

Já em relação à ocupação profissional dos pais e mães da maioria dos estudantes, observou-se certa linearidade em profissões de baixo prestígio social. As funções identificadas foram: doméstica, cabeleireiro, metalúrgico, alfabetizador, trabalhador de desmatamento ambiental, auxiliar de serviços gerais em uma escola e em área rural. Essas características delimitaram o espaço do possível para esses alunos e suas trajetórias. Tanto do ponto de vista escolar quanto das ocupações profissionais, os indivíduos de uma mesma classe social tendem a ter diferenças ligadas a critérios sociais ou culturais que distinguem subgrupos dentro da mesma classe (BOURDIEU; PASSERON, 1992, p. 116). Em relação aos entrevistados, percebe-se uma evolução tanto da escolaridade quanto das posições socioprofissionais em relação às de seus pais.

O pai e a mãe de Laura, embora possuíssem nível médio de escolaridade, ocuparam profissões de maior prestígio social. O pai de Laura foi servidor público na Câmara dos Deputados e sua mãe foi professora, mas virou, posteriormente, dona de casa, após se casar. "Ela se dedicou essencialmente à educação dos filhos" (Laura). Nessa fala, percebe-se a importância da figura materna para a transferência de capital cultural, bem como a influência do meio familiar para a transmissão do capital e sua ascensão no espaço social. Segundo Bourdieu (1979, p. 3), tal prática traz consigo “[...] o mais oculto e determinante social dos investimentos educativos, a saber, a transmissão doméstica do capital cultural”.

Laura apresentou seu pai como um autodidata. Ela relata que ele estudava computação, eletroeletrônica, falava alemão e trabalhava com rádio e televisão, além de preparar as sessões legislativas. Laura teve acesso a diversas formas de capital. Por isso, pode-se até justificar seu gosto pela arte, pela estética e seu acesso ao curso de graduação em uma IES pública.

Segundo Maton (2018, p. 75),

[...] as práticas sociais se caracterizam por regularidades - filhos da classe operária tendem a obter empregos de classe operária (como Willis [1977] afirmou), leitores de classe média tendem a apreciar literatura de nível intelectual médio, e assim por diante -, mas não existem regras explícitas que ditam tais práticas.

Essa perspectiva pode ser representada pela seguinte fala de Laura:

[...] eu tenho uma ligação muito forte com a memória, a arquitetura de exposições, o designer de interiores e a restauração. Cheguei a passar em um concurso na Câmara dos Deputados como restauradora, mas não assumi, porque já estava casada e com filhos pequenos. Então, eu tenho uma área de conhecimento bem horizontal em torno da arte e da educação, principalmente. (Laura).

Com relação ao incentivo familiar para a continuidade dos estudos, Laura afirmou:

[...] nunca foi verbalizado nada, era mais ambiental, por causa dos colegas. Havia um entendimento de que a gente não devia parar de estudar. Nunca foi incentivado a gente arranjar emprego, então, era natural seguir pela área acadêmica até a universidade. (Laura). 
Desse modo, a partir da fala da entrevistada, cujos pais detinham estabilidade socioeconômica, somada ao repertório cultural do pai, há todo um ambiente familiar propício, que gerou certa naturalização em relação à sequência dos estudos até a chegada à universidade pública. Assim, podemos dizer que a entrevistada possuía o tempo como requisito facilitador no processo de apreensão do mundo social e material, derivado de um estilo de vida privilegiado (THOMSON, 2018, p. 108).

A família assume um papel de destaque e é considerada um dos lugares de excelência de acumulação dos diferentes tipos de capital. Inclusive, ela é responsável pela transmissão entre as diferentes gerações.

Isso fica bastante evidente quando questionamos os entrevistados a respeito da escolaridade dos seus filhos. Todos os filhos dos entrevistados tiveram acesso à graduação. $\mathrm{O}$ filho de Dalva possui o título de doutor por uma IES pública brasileira. Os filhos de Laura tiveram a oportunidade de realizar os estudos nos Estados Unidos. Nesse sentido, ainda é significativa a contribuição de Bourdieu (1996, p. 131) no que se refere ao capital cultural e à sua transmissão entre as gerações, nestes termos:

De fato, a família tem um papel determinante na manutenção da ordem social, na reprodução, não apenas biológica, mas social, isto é, na reprodução da estrutura do espaço social e das relações sociais. Ela é um dos lugares por excelência de acumulação de capital sob seus diferentes tipos e de sua transmissão entre as gerações: ela resguarda sua unidade pela transmissão e para a transmissão, para poder transmitir e porque ela pode transmitir.

A representação que emergiu a partir das atitudes dos pais quanto à importância do capital cultural para as futuras gerações demonstra os valores de uma determinada geração e seus impactos sobre a trajetória dos agentes no espaço social mais amplo. O próprio capital cultural dialoga com sua realidade e sofre mutações. Eis aqui como Bourdieu (2007) o caracterizou, ainda se remetendo à noção de habitus, à estrutura estruturante e estruturada que tende à estabilidade, mas que não é engessada: "Tais práticas e ideologias poderão atualizar-se em ocasiões mais ou menos favoráveis que lhes propiciam uma posição e uma trajetória determinadas no interior de um campo intelectual que, por sua vez, ocupa uma posição determinada na estrutura da classe dominante" (BOURDIEU, 2007, p. 191).

Com relação aos irmãos dos entrevistados, nenhum deles possui título de mestrado ou doutorado, predominando a formação em cursos de graduação. Com orgulho e entusiasmo, Davi disse:

Ninguém te pergunta se você já fez a pós-graduação, mestrado e doutorado. As pessoas perguntam se você é formado, não é isso? Então, até a graduação, é uma obrigação da família e da sociedade. Já o mestrado e o doutorado é uma satisfação sua. Você entendeu? Quando eu chego à minha cidade todo mundo sabe que eu sou um doutor, eu não recebi o meu diploma ainda, porque estou esperando marcar a defesa. Na minha cidade, que é pequeninha, eu sou o único doutor. É o primeiro doutor que vai ter. Não tem mais ninguém. (Davi).

Nessa fala, ficam nítidos a valorização atribuída ao capital cultural institucionalizado e seu possível desdobramento nas demais formas, como, por exemplo, o capital 
simbólico. Nesse sentido, Bourdieu (2007, p. 112) trata da importância do simbólico e seu contexto local.

\begin{abstract}
[...] a procura dos critérios "objectives" de identidade "regional" ou "étnica" não deve fazer esquecer que, na prática social, estes critérios (por exemplo, a língua, o dialecto ou o sotaque) são objectos de representações mentais, quer dizer, de actos de percepção e de apreciação, de conhecimento e de reconhecimento em que os agentes investem os seus interesses e os seus pressupostos, e de representações objectais, em coisas (emblemas, bandeiras, insígnias, etc.) [sic]. (BOURDIEU, 2007, p. 112).
\end{abstract}

Assim, o reconhecimento dos moradores de uma cidade pequena, por exemplo, traz à tona representações mentais sobre a escolarização e desvenda a satisfação que o aluno demonstra em ser o primeiro a ocupar essa posição no campo, aglutinando à sua trajetória um símbolo regionalmente reconhecido, visto que ele conseguiu "[...] alocar melhor seus investimentos escolares e obter o melhor lucro de seu capital cultural. Essa é uma das mediações através das quais o sucesso escolar - e social - se vincula à origem social" (BOURDIEU, 1996, p. 42).

O capital social (BOURDIEU, 1996) também emerge como dado da pesquisa. Lucas tratou dos laços de confiança, solidariedade e cooperação entre o grupo de estudantes que cursavam a mesma universidade que a sua:

Eu cheguei à escola em que eu trabalhava e anunciei o curso para alguns amigos. Éramos um grupo de seis que entramos nesse sonho e fomos até lá. Esse fator foi muito positivo para o desenvolvimento e a conclusão do curso. Todos concluíram o curso, e três retornaram para cursar o doutorado.

[...] duas dessas pessoas são meus compadres. Essa relação de compadres se estabeleceu após o mestrado. No início, a gente alugou dois quartos e, quando os gastos começaram a pesar, ficamos todos no mesmo quarto. Nós dividíamos a hospedagem, a alimentação, foi uma relação muito boa. (Lucas).

Esse capital social (BOURDIEU, 1982), sem dúvidas, facilitou a ação desses indivíduos, pelo fato de compartilharem valores, atitudes e crenças, possibilitando a motivação coletiva para a inserção e a conclusão do curso. Dessa forma, os estudantes expressam sentimentos de grande esforço e pertença à pós-graduação stricto sensu, ocupando um espaço comum e compartilhado, visto que eles se sentem 'no mesmo barco'. Está presente nesse contexto da relação "[...] aquilo que Aristóteles chamou de philia - o gostar ou a 'amizade' - onde os envolvidos não competem economicamente uns com os outros" (GRENFELL, 2018, p. 217).

\title{
Sobre a modalidade do curso stricto sensu e o reconhecimento do diploma
}

Dos oito entrevistados, apenas Fernando, Jorge e Lucas participaram de processos seletivos de pós-graduação stricto sensu no Brasil.

Dois foram os aspectos centrais e mobilizadores para a opção desses estudantes pela pós-graduação stricto sensu em outros países do Mercosul: a conveniência e a oportunidade. A conveniência e a oportunidade se conjugaram diante da possibilidade de realizar o 
curso dentro das limitações individuais no tocante ao tempo, aos compromissos no trabalho e à disponibilidade. ${ }^{7}$ Disse Dalva:

[...] aqui na minha cidade não tinha curso de pós-graduação, de mestrado. Então, eu teria que sair daqui da minha cidade e me deslocar para outra cidade, para a capital do estado, que é distante, mais ou menos, 500 quilômetros. Eu teria que me deslocar para essa cidade toda semana, o que ficaria inviável, porque, no meu trabalho, eu não conseguiria liberação para isso. Para sair daqui toda semana, me deslocar para estudar fora. Então, não havia essa possibilidade. E quando eu vi essa possibilidade de fazer um curso fora, que oferecia a possibilidade de fazer um curso em tempo intensivo, nas férias, aí eu vi a possibilidade de fazer um mestrado, foi por isso que eu fui fazer fora. (Dalva).

Perguntados sobre os aspectos que os motivaram a ingressar no curso, os entrevistados afirmaram que foi a satisfação pessoal, a aquisição de novos conhecimentos, a obtenção do título, a chance de obter o diploma reconhecido no Brasil, a possibilidade de inspirar outras pessoas, como familiares, amigos e alunos, bem como a progressão financeira na carreira. Disse Jorge: "Para quem trabalha na universidade não há outra escolha. Então, o mestrado e o doutorado são fundamentais". Vale a pena ressaltar a fala de Laura; inicialmente, ela afirmou que a busca pelo curso não foi algo planejado, mas sim um incentivo por parte de um grupo de colegas e do marido, que precisavam de uma pós-graduação stricto sensu para sua progressão funcional como professores universitários. Diante disso, ela resolveu se juntar ao grupo: "Então, não foi uma coisa muito bem planejada, no meu caso particular. E para a aposentadoria: um mestrado eu levo para aposentadoria; igual à especialização que eu já tinha feito, em educação corporativa" (Laura).

No que diz respeito às especificidades da forma de desenvolvimento do curso, os estudantes afirmaram que se trata de uma modalidade mais intensiva/imersiva e que as metodologias utilizadas durante as aulas variam de acordo com a natureza dos conteúdos e as opções dos grupos de orientação quanto aos meios para a mediação pedagógica. Compulsando os sítios eletrônicos das instituições, percebemos que vários cursos possuem a opção presencial ou a distância (virtual). Entretanto, o ensino presencial segue a lógica intensiva e divide-se em módulos, o que gera um descompasso em comparação com a oferta presencial brasileira de cursos acadêmicos de pós-graduação.

Os recursos didáticos mais citados foram: aulas expositivas, discussão de textos, vídeos, oficinas e seminários. Quanto às tecnologias utilizadas, os entrevistados citaram: a internet, o WhatsApp, o e-mail e os conteúdos disponíveis em plataformas online. Apesar de os participantes afirmarem que o curso foi estritamente presencial, Fernando nos relatou que "[...] as atividades de produção acadêmica foram realizadas online". E Jorge nos disse que "[...] As disciplinas eram todas em módulos, só a orientação foi realizada a distância". A fala de Laura abordou outro ponto relevante:

\footnotetext{
7 A conveniência e a oportunidade apareceram no discurso dos que participaram de processos seletivos no Brasil, também associadas às críticas sobre a transparência na seleção dos cursos de mestrado e doutorado nas instituições públicas brasileiras; sobre o fato de que a instituição que promove a seleção privilegia mais os que estudaram nela do que os de fora; de que há poucas vagas na seleção; do número reduzido de linhas de pesquisa; de que não teriam bolsa de estudos; entre outros aspectos.
} 
[...] a orientação foi realizada a distância. Foi feita por e-mail, WhatsApp e por mensagem de texto, mas o orientador esteve aqui no Brasil presencialmente e foi muito difícil. Ele vai para vários estados: Nordeste, Norte, porque os estudantes formam grupos de orientação. Mas o meu foi particular mesmo. Ele já vinha e eu acertei com ele.

Nesse ponto, temos um modelo de orientação bastante diferente do padrão nacional, pois a orientação, via de regra, fica circunscrita aos limites do campus universitário. Claro que aqui as ferramentas de comunicação também são utilizadas, mas a figura de um orientador-peregrino não é comum.

Do mesmo modo, Davi nos disse:

Eu organizei a vinda do orientador. O meu orientador era paraguaio, mas ele teve uma fase aqui no Brasil, inclusive na [Universidade de São Paulo] USP, e em outras universidades como professor. Ele tem doutorado na área de comunicação também. A maioria do pessoal lá tem, no mínimo, um ou dois doutorados. Não tem ninguém que lecione lá sem ter doutorado. Os orientandos se organizam, pagam a passagem e as diárias, e os orientadores veem ao Brasil. Como eu organizei o encontro, ele fez tudo para mim, a formatação, a revisão e a minha tese não teve nenhuma vírgula para consertar.

Procuramos informações oficiais que tratassem do papel do orientador nos cursos. Não encontramos funções específicas, e até mesmo os entrevistados tiveram dificuldades em obtê-las. Chamou-nos a atenção o fato de haver uma cotização entre os orientandos para que o orientador pudesse vir ao Brasil quando da escrita da dissertação ou tese. Esse tipo de atividade ocorre de modo informal e não institucionalizado, ou seja, é um pacote 'contratado' pelo orientando. Ademais, salta aos olhos o fato de o orientador executar atividades estranhas ao modelo nacional, como formatar o trabalho. Assim, pareceu-nos que o papel do orientador ultrapassa a atuação intelectual e chega a alcançar atividades instrumentais.

Por outro lado, Lucas revelou que "[...] cada um de nós tinha o acesso à plataforma para postar atividades que seriam avaliadas pelo professor de cada matéria". Quando questionamos Lucas sobre a modalidade educacional do curso, ele afirmou: "Eu não diria $\mathrm{EaD}$, porque a gente tinha os encontros. Então, eu diria que foi, assim, semipresencial, o que seria mais adequado".

Vivian, corroborando a fala de Lucas, afirmou:

A gente tinha o virtual, nós fazíamos os trabalhos e os enviávamos. É semipresencial. Durante a parte presencial, ela é bem forte, porque são 25 dias, 12 horas por dia. Depois, os 4 ou 5 meses que a gente fica fora é virtual, e a gente conversa muito durante esse período.

Em consonância com a abordagem da reflexividade reflexa (BOURDIEU, 2008), observamos nas falas de alguns dos entrevistados a intenção de definir a modalidade como presencial, provavelmente para justificar uma possível compatibilidade com os programas de pós-graduação stricto sensu nacionais. Pareceu-nos que a própria pesquisa, originária de instituição pública federal com programa de pós-graduação acadêmico na modalidade presencial, gerou certa inquietação, pois, mesmo em momentos que não tratavam da 
modalidade do curso, os entrevistados procuravam fazer um paralelo com os elementos presenciais encontrados nos cursos brasileiros. Além disso, foram realçadas características comuns entre quem realizava as entrevistas e os entrevistados, como, por exemplo, o fato de serem servidores públicos. Ficou a impressão de que se tratava da mesma 'família'. Durante a entrevista, tinha-se a impressão de que os entrevistados estavam se sentindo 'julgados' em relação ao curso que realizaram, ou seja, nas respostas parecia pairar a preocupação de enaltecer o próprio curso.

A presença de professores brasileiros também foi destacada. Davi revelou-nos que "[...] tem até professores brasileiros lá na universidade. De diversos lugares do Rio, da Federal do Rio e de Tocantins". Jorge também reconheceu a importância da presença de professores brasileiros para legitimar a oferta do curso em outro país do Mercosul:

[...] uma boa parte dos professores eram professores brasileiros que trabalhavam na pós-graduação aqui. Isso para eles era uma carta na manga. Eu tive diversos professores bolivianos, argentinos e paraguaios. Então, tinha essa mistura. A carga horária lá é bem superior do que a de qualquer mestrado aqui no Brasil. Era uma organização particular com um jeito europeu. Então, o cuidado e esse contato com os alunos era muito bem feito. (Jorge).

Laura nos disse: "É presencial, né? Porque, no curso mesmo, os módulos são em imersão. 30, 40 dias em imersão". Embora se interrogasse sobre o fato de a modalidade ser presencial ou não, Laura frisou:

Foi uma oportunidade de vivenciar outras coisas e de uma maneira muito interessante que é essa imersão. Eu até andei procurando, nas universidades aqui no Brasil, e não tem essa categoria. Eu acho que podia ter, sabe? Essa coisa de passar as férias estudando ou montando projeto, formulando hipóteses. É uma modalidade que podia ter aqui no Brasil. É uma coisa que a gente não tem, porque as pessoas que trabalham não conseguem dedicar, por exemplo, um período do dia para estudar. Então, essa coisa da imersão de você conseguir concentrar um período nisso para fazer, isso eu achei muito interessante nessa experiência. (Laura).

No que se refere à modalidade, Tatiana avaliou o curso da seguinte forma:

[...] era presencial. A minha orientação foi com uma professora brasileira, e a gente tinha os encontros presenciais quando eu estava lá, mas a gente também se comunicava virtualmente quando eu estava no Brasil. Eu ia e ficava 25 dias estudando de 8 horas da manhã até 8 horas da noite. De segunda a sábado. Então, era presencial.

Jorge afirmou: "Lá era tipicamente presencial." De maneira semelhante, Fernando nos disse que o curso "era totalmente presencial". Porém, quando foi nos explicar como se dava a presencialidade, encontramos alguns pontos contraditórios:

Ela é presencial em um primeiro momento, depois ela se torna virtual. Presenciais foram somente dois encontros, e virtuais foram vários, né? Mas a gente se falava mais por telefone. (Fernando). 
Quando questionado sobre as horas de dedicação ao curso, Lucas nos disse:

Em média, quatro horas, mas dependia da atividade a ser entregue no sistema. $\mathrm{Na}$ reta final, havia mais dedicação. Algumas atividades eram entregues por e-mail e aconteciam também as webconferências com os professores online. Tínhamos contato pelo Facebook e pelo WhatsApp.

A partir das falas de Lucas e Vivian, deduz-se que se trata da oferta de curso na modalidade semipresencial.

Assim, questionamo-nos quanto à percepção que os entrevistados possuem sobre o ensino semipresencial. Nossa hipótese é que os estudantes querem se adequar às regras do jogo da pós-graduação no Brasil, a fim de obterem o reconhecimento dos seus diplomas, pois o discurso de que se trata de uma formação presencial, mesmo destoante do modelo nacional, parece-nos uma prática legitimadora do mundo social e fator fundamental para transformar o diploma em capital reconhecido no Brasil.

Com relação aos aspectos positivos de realizar o curso de pós-graduação no exterior, os entrevistados afirmaram que os principais pontos foram: a possibilidade de vivenciar outras realidades e obter novos aprendizados; a oportunidade de conhecer uma nova cultura e fazer amizades; a facilidade em permanecer no programa de pós-graduação e prosseguir no doutorado; a valorização dos professores, das universidades e da comunidade de estudantes brasileiros; e os valores das mensalidades, inferiores aos dos programas brasileiros. Dentre esses aspectos, destacamos a maior viabilidade financeira de cursar uma pós-graduação em países do Mercosul do que de realizá-la em instituições privadas brasileiras, mesmo com os dispêndios de deslocamento e estadia. Essa inquietação nos levou a pesquisar rapidamente quanto custa um mestrado ou doutorado em instituições privadas nacionais. Verificamos que o último edital de mestrado de uma universidade particular de Brasília apontou valores em torno de U\$ 12,5 mil, desde que não houvesse reprovação em disciplinas por parte do aluno; para programas de doutorado, o valor é um pouco mais elevado, na casa dos U\$ 20 mil. Já em um sítio eletrônico de uma instituição paraguaia, constatamos que o valor orbita em torno de U\$ 3,5 mil para o mestrado e em torno de U\$ 4,5 mil para o doutorado. Mesmo que tenha sido uma rápida pesquisa na internet, verifica-se que o valor investido pelos alunos desejosos de cursar um mestrado em uma instituição privada no Brasil é muito superior ao valor do curso ofertado pelo Paraguai.

Quanto aos aspectos negativos, os entrevistados destacaram: o deslocamento para outro país, a distância da família, o frio durante os meses de junho e julho, o fuso horário e do fato terem que tirar o passaporte e realizar exames médicos. Três deles destacaram como ponto negativo a obrigação de submeter o título aos processos de reconhecimento de diplomas no Brasil. Das oito pessoas que cursaram o mestrado, nenhuma teve o diploma reconhecido no Brasil. ${ }^{8}$ Apenas quatro entrevistados conhecem pessoas que tiveram o título

8 Houve o caso excepcional de um pós-graduando que cursou o mestrado em uma instituição no Paraguai e foi aprovado em concurso para docente em uma universidade pública. Segundo o entrevistado, o edital do concurso não previa a exigência do reconhecimento do diploma do mestrado. Posteriormente, como docente da universidade pública, o entrevistado relata que cursou o doutorado em país europeu, e o diploma foi reconhecido por uma universidade pública federal. O curriculum lattes do entrevistado informa o período do afastamento - quando era professor assistente -, atesta que ele recebera bolsa de doutorado de uma fundação de apoio à pesquisa brasileira e, como dito, teve o diploma reconhecido. 
reconhecido no país. Esse indicativo demonstra que o reconhecimento do capital cultural institucionalizado não é um prêmio acessível a todos os estudantes.

Apenas Laura afirmou ter pensado em desistir do curso: "Sim, por causa da orientação a distância. Apesar de eu estar com tudo estruturadinho, na hora de montar o trabalho, de validar aquilo e ter um olhar mais apurado do orientador, ficou difícil". Por outro lado, quando a questionamos sobre qual o fator que mais contribuíra para sua permanência, ela nos afirmou que foi o fato de seu curso de pós-graduação estar vinculado à licença-capacitação remunerada. Assim, caso ela desistisse, teria que ressarcir os cofres públicos. Logo, isso mobilizou a estudante a finalizar o curso.

A fala de Jorge apresenta um movimento consciente quanto aos riscos implicados na escolha pela pós-graduação fora do Brasil:

Uma das principais coisas que a gente tem que aprender nessas horas é acreditar naquilo que estamos fazendo. Eu acreditei muito mais em mim do que na própria instituição. Depois que as coisas terminaram, eu passei a acreditar mais na instituição, mas, no início, eu também não acreditava tanto. Então, fiz algumas escolhas, eu escolhi um orientador brasileiro, de uma instituição bem conhecida no Brasil. O que mais me fez permanecer foi acreditar naquilo que eu estava fazendo. (Jorge).

Percebe-se, na fala do estudante, que ele tinha consciência da baixa reputação dos cursos oferecidos pelas universidades do país vizinho. Essa percepção, interiorizada por meio da subjetividade, foi obtida indiretamente, pois os entrevistados sabiam que haveria outra batalha a ser travada: o reconhecimento do curso, que não é automático.

É importante salientar que o Brasil dispõe da Plataforma Carolina Bori, um sistema informatizado criado pelo MEC, que agrega instituições de educação superior públicas e privadas, além de recepcionar e oferecer um conjunto de informações sobre os processos de revalidação e de reconhecimento dos diplomas estrangeiros. Pela plataforma, o pós-graduando tem informações sobre as instituições que já reconheceram diplomas similares aos seus. ${ }^{9}$ Assim, a plataforma contribui tanto para a gestão quanto para a verificação do fluxo do processo pelo pós-graduando. Para ser reconhecido, o diploma de pós-graduação de país estrangeiro deve pertencer à mesma área de conhecimento e a um nível equivalente ou superior ao do curso no Brasil. Deve ainda ser fundamentado no mérito, de acordo com as condições acadêmicas do programa cursado, considerando as diferenças existentes entre as formas de funcionamento dos sistemas educacionais, das instituições e dos cursos em ambos os países, respeitadas as normas complementares específicas de cada universidade ${ }^{10}$ (BRASIL, 2016).

A Capes tem se preocupado com a ação de agências que aliciam os estudantes, principalmente do Norte e Nordeste, persuadindo-os a fazer matrícula em cursos de pós-gradua-

9 Plataforma Carolina Bori. Disponível em: http://plataformacarolinabori.mec.gov.br/usuario/acesso\#. Acesso em: 20 jan. 2021.

10 Pelos limites do artigo, não é nosso objetivo tecer análises comparativas entre os sistemas de pós-graduação no Brasil e em outros países do Mercosul, mas sim nos centrar nas questões que os pós-graduandos levantaram sobre a percepção da modalidade cursada e no que a literatura tem indicado a respeito do indeferimento dos diplomas e de outras questões emergentes. 
ção stricto sensu, sobretudo no Paraguai, com o discurso de que seus diplomas serão reconhecidos de forma automática no Brasil e de que obterão a progressão funcional em suas carreiras, no caso de servidores públicos (CAPES, 2019c). As aulas são realizadas de forma intensiva, durante os períodos de férias escolares, em janeiro e julho (CAPES, 2019c).

Vilarinho e Gonzalez (2014, p. 1068), ao analisarem pedidos de reconhecimento dos títulos de pós-graduação stricto sensu, identificaram que $84 \%$ das solicitações eram provenientes de instituições do Paraguai. Quando da análise da oferta desses cursos, as autoras constataram a predominância da modalidade intensiva, presente em $62,5 \%$ das demandas, ou seja, as aulas presenciais, em sua maioria, concentravam-se nos meses de janeiro e julho, normalmente meses de férias. Vilarinho e Gonzalez (2014) conjecturam que um dos fatores que levam os brasileiros a realizar cursos em países do Mercosul é o fato de que há uma grande concentração regional da oferta de educação superior no Brasil. Os dados apresentados pelas autoras dão conta de que $68 \%$ dos cursos de mestrado e doutorado do país estão concentrados nas regiões Sul e Sudeste (VILARINHO; GONZALEZ, 2014, p. 1060). Sobre esse aspecto, uma das questões estruturais da pós-graduação no Brasil é a concentração dos cursos nas regiões mais desenvolvidas. Sua evolução recente "[...] colaborou para a desconcentração das atividades na Região Sudeste, que reduziu sua proporção no total de programas de $61 \% \mathrm{em}$ 1988 para 44\% em 2016 (CAPES, 2017 apud COLOMBO, 2018, p. 247). Além do desafio da expansão da pós-graduação, o autor considera relevante que o tema da equidade ganhe espaço na agenda das políticas da pós-graduação brasileira, "[...] a fim de garantir que cursos de mestrado e doutorado não constituam um elemento de perpetuação ou elevação da desigualdade social no país, especialmente ao considerar que a maior parte dessas atividades é gerida e financiada com recursos públicos" (COLOMBO, 2018, p. 247).

Logo, diante das questões estruturais da pós-graduação no Brasil, alunos desejosos de cursar uma pós-graduação em regiões com menor oferta seriam submetidos a uma concorrência bem superior. Além de as exigências do processo avaliativo brasileiro para o ingresso em cursos deste nível serem mais elevadas, Vilarinho e Gonzalez (2014) concluem que dois fatores preponderam na escolha dos alunos: 1) a oferta é pouca, e 2) a exigência alta. Criticando a postura puramente mercadológica de instituições estrangeiras que buscam alunos no Brasil com a promessa de um diploma rápido e válido, as pesquisadoras apresentam dados de 2014 que mostram que o não reconhecimento atinge mais de $80 \%$ das solicitações realizadas (VILARINHO; GONZALEZ, 2014, p. 1064).

Mazzuoli (2011) chama de "má-fé comercial" a postura de universidades estrangeiras que cooptam alunos em outros países e não dão transparência para o fato de que o diploma não terá nenhum efeito legal interno imediato no Brasil. Assim sendo, propostas de cursos mais baratos e com a duração menor podem se transformar em verdadeiras armadilhas, visto que não há mecanismo de reconhecimento automático no país (MAZZUOLI, 2011, p. 22). É fundamental que o aluno procure conhecer o programa do curso de pós-graduação e saber se há algum curso correlato no Brasil, além de ter ciência de que há custos envolvidos na requisição do reconhecimento.

Tatiana, ao tratar do processo de reconhecimento de diplomas no Brasil, exprime sentimentos de angústia, frustração e tristeza, pois "[...] o meu processo de revalidação de diplomas foi uma fraude. Eu e muitas pessoas aqui da minha cidade fomos enganados por 
uma pessoa daqui e, hoje, o processo encontra-se em investigação pela polícia". Tatiana relata que seu título de mestrado chegou a ser reconhecido por uma universidade pública federal, e, na ocasião, ela o publicou nas redes sociais. Em linhas gerais, a forma e o conteúdo do diploma reconhecido eram semelhantes aos expedidos por instituições brasileiras. Segundo a entrevistada, o diploma the fora entregue em papel timbrado pela universidade e contava com a ata de apostilamento e a assinatura do reitor. Ela ainda nos relatou que a fraude só foi revelada porque algumas pessoas que tiveram o diploma reconhecido da mesma forma, ou seja, por meio do serviço de despachante, estavam participando de um processo seletivo para ministrar aulas em uma instituição de ensino superior, e o responsável pelos recursos humanos de tal empresa ligou para a universidade federal com o intuito de averiguar a veracidade do documento. Em matéria noticiada pelo jornal Correio Brasilense (ALCÂNTARA; BERNARDES, 2015), a Polícia Federal já investigava um esquema de fraude envolvendo a falsificação de diplomas. Logo, percebe-se que tal crime já vem sendo praticado há algum tempo no Brasil, cabendo investigação policial.

Outro aspecto interessante são as justificativas para a negativa de diplomas de pós-graduação estrangeiros sustentadas pela Universidade Federal de Santa Catarina (UFSC), pois refletem o que outros autores relatam, a saber:

As principais razões dos indeferimentos dos pedidos foram relacionadas à: fragilidade da tese/ falta de contribuição teórica/ não apresentação da originalidade essencial para trabalho de doutorado/ conclusão não condizente com objetivos iniciais da pesquisa/falta de clareza ao problema pesquisado/trabalho sem a profundidade requerida/ caracterizado como revisão bibliográfica e não resultado de pesquisa científica/problemas de forma e conteúdo/sem requisitos mínimos para dissertação/trabalho compatível com curso de especialização/ compatível com graduação/conteúdo de curso contemplado no reconhecimento de outro título/ realizado em sistema de coautoria/incompatibilidade com o mestrado no Brasil em carga horária e defesa perante banca/ desatualização das referências bibliográficas e outros. (NICHELE; COSTA; PRÉVE, 2009, p. 11).

Percebemos que muitos dos aspectos ensejadores de negativas quando do reconhecimento são ligados a fatores internos à universidade, pois a própria autonomia universitária, quanto à formulação dos currículos e programas, baliza todo o processo de reconhecimento. Assim, por mais que existam exigências legais, a multiplicidade de programas pode ser fator fundamental para o êxito do reconhecimento. Talvez por se tratar de um artigo produzido em 2009, não é citada a modalidade em que o curso foi ofertado, o que nos leva a pensar em cursos exclusivamente presenciais. A experiência relatada demonstrou que os demandantes, em sua maioria, são brasileiros e que poucos estrangeiros buscam o reconhecimento naquela universidade (NICHELE; COSTA; PRÉVE, 2009, p. 12).

Quanto à diferença que o diploma fez na vida dos estudantes, eles afirmaram que o documento lhes oportunizou o exercício da profissão docente, a progressão na carreira, o aumento na remuneração e a mudança de cargo.

Dalva nos disse que

A diferença foi que me abriu portas de trabalho. Assim que eu concluí o curso, eu fui convidada para trabalhar. Eu fui indicada para trabalhar em uma insti- 
tuição de ensino superior. Já estou trabalhando nessa instituição há cinco anos e no ano passado fui convidada para trabalhar em outra instituição também de ensino superior. Então, hoje, estou trabalhando com duas instituições de ensino superior. (Dalva).

Em contraste com a fala desses estudantes, Fernando nos declarou que,

Na verdade, o diploma não faz diferença, porque ele é só um papel. O que faz diferença é o conhecimento. Eu não fui buscar um diploma. Eu fui buscar conhecimento. Porque o diploma você consegue fácil. (Fernando).

Nesse sentido, ele revelou que

Lá é assim. Os horários de $8 \mathrm{~h}$ até $12 \mathrm{~h}$, de $13 \mathrm{~h}$ até $18 \mathrm{~h}$ e de $19 \mathrm{~h}$ até $21 \mathrm{~h}$. Então, você pode chegar mais tarde, sair mais cedo. Você faz o grupo de cinco pessoas, duas fazem o trabalho e apresentam. E o restante vai para as noites de Assunção, bailes e choperias. E, no final, você tem a nota do grupo. Você copiou e colou e tem a nota. O projeto, você contrata o orientador, mas se pegar no jornal tem "faço trabalhos acadêmicos", e você apresenta e recebe o diploma. Você só apresenta algo que você não fez. Na Secretaria onde trabalho, para quem tem [diploma de pós-graduação] lato sensu são 10\% sobre o vencimento. Os [diplomas] lato sensu são todos comprados. (Fernando).

A fala acima descreve os meandros da formação e nos alerta para uma possível ruptura na busca pela qualidade de ensino. É evidente que tal aspecto pode igualmente ocorrer em cursos ofertados no Brasil, mas essa perspectiva vai ao encontro de problemas relatados por outros pesquisadores quanto à dificuldade de reconhecer diplomas: a falta de especificação da carga horária real em cursos de pós-graduação ofertados no Mercosul. A abertura do mercado educacional gerou uma forte demanda por serviços especializados em fazer trabalhos acadêmicos. O entrevistado relata que é comum as pessoas optarem por esse tipo de serviço em cursos lato sensu.

Sobre os principais projetos após o término do curso, a maioria disse ter aspirações no campo da docência. Apenas um afirmou ter ambições relacionadas ao concurso para a magistratura federal. Inquestionavelmente, os entrevistados atribuem ao curso de pós-graduação um papel central na concretização de seus projetos relacionados à docência no ensino superior. As falas ainda nos permitem concluir que, na percepção dos entrevistados, o ambiente institucional era excelente no que diz respeito às instalações físicas, aos aparatos tecnológicos, à gestão e à equipe de apoio. A relação entre os docentes e os estudantes foi avaliada de forma muito positiva. Todos os entrevistados afirmaram que os professores superaram suas expectativas em relação à atuação pedagógica, à orientação e à aptidão para atender às suas necessidades, carências e dificuldades quanto aos conteúdos ministrados e ao idioma.

Um aspecto que nos chamou atenção foi a relação de confiabilidade e segurança quanto à oferta das instituições na percepção dos entrevistados. Cinco deles, baseados na experiência do programa de mestrado, optaram por continuar a carreira acadêmica e realizar o curso de doutorado. 


\section{Conclusĩo}

Identificamos que, no geral, os estudantes que se posicionam no campo da pós-graduação stricto sensu em países do Mercosul são pessoas estabelecidas profissionalmente e maduras, em razão das dificuldades e obstáculos que tiveram de enfrentar antes de retomarem os estudos, o que lhes faz encarar melhor as novas condições ao saírem do Brasil e buscarem a pós-graduação stricto sensu.

A faixa etária dos estudantes, em sua maioria, é superior à daqueles que estão em cursos presenciais no Brasil. A maior parte deles vislumbra a docência na educação superior após o término do curso. Os estudantes se entregam a esforços paralelos para possuir o capital cultural institucionalizado - título escolar e, consequentemente, capital simbólico - e o reconhecimento do diploma.

Com relação ao nível de formação escolar dos pais e às suas profissões, identificamos, na sua maioria, respectivamente, baixo capital cultural e ocupações profissionais de menor prestígio social. Apenas a mãe de uma das entrevistadas possui diploma de ensino superior. A pós-graduação stricto sensu (mestrado/doutorado) cria, no ciclo geracional, um novo ponto de ancoragem, que, possivelmente, transmitir-se-á aos 'herdeiros' em termos de elevação da escolaridade. É possível afirmar a tendência da elevação do capital simbólico (diploma) dos filhos oriundos das classes populares em cursos de graduação ao longo das gerações. Isso ficou bastante evidente quando questionamos os entrevistados a respeito da escolaridade de seus filhos, pois os filhos com idade de acesso ao ensino superior já fizeram ou estão cursando alguma graduação superior. Uma das entrevistadas afirmou que seu filho possui título de doutor obtido em uma universidade federal brasileira, e a outra tem filhos estudando nos Estados Unidos. A universalização da educação básica e a expansão da educação superior brasileira, tanto no âmbito público quanto no privado, explicam a diferença de oportunidades entre a gerações dos pais, a dos próprios estudantes e a de seus filhos. Inclui-se nessa expansão a oferta de cursos de graduação a distância, principalmente por instituições privadas. Consequentemente, a escolarização superior dos pais influencia na graduação acadêmica dos filhos.

Todavia, esses aspectos não minimizam a desigualdade social e educacional existente no Brasil.

Com relação à modalidade do curso de pós-graduação stricto sensu em países do Mercosul, verificamos que a situação educativa é permeada por ambas as modalidades: presencial e a distância. Isso constitui um cenário educativo semipresencial. Os estudantes afirmaram que a escolha do curso se deu por motivos como modalidade flexível, acessibilidade financeira, possibilidade de conciliar os estudos com as férias e, implicitamente, por processos seletivos menos rigorosos.

Percebe-se que a ampliação da oferta dos cursos de graduação e pós-graduação nas modalidades educacionais a distância e semipresencial tem provocado profundas alterações no mercado. No caso do Brasil, o baixo custo das mensalidades na graduação, a modalidade do ensino, a redução da carga horária e a precarização do trabalho do professor/tutor potencializam transformações no valor do diploma, tanto econômicas quanto simbólicas, pois, ao se tornar mais acessível, acaba por se desvalorizar. Diante da edição da Portaria 
Capes $n^{\circ}$ 90/2019, que regulamenta os programas de pós-graduação stricto sensu na modalidade EaD, cabe-nos levantar alguns questionamentos e apontar possíveis tendências. ${ }^{11}$

O primeiro questionamento é o seguinte: novas políticas educacionais, a partir de mestrados e doutorados acadêmicos na modalidade educacional a distância, poderão viabilizar uma oferta com maior equidade no Brasil? Não teremos equidade educativa com a oferta da pós-graduação stricto sensu a distância ao alcance de todos, pois a tendência será a concentração da oferta em poucos cursos. Entre esses poucos cursos estarão os da educação e os tecnológicos. A título de exemplo, o típico aluno da graduação a distância está matriculado em curso de licenciatura e é oriundo da rede privada (INEP, [ca. 2020]). É importante também ressaltar o crescimento das matrículas a distância no ensino superior tecnológico (INEP, [ca. 2020]). A expansão tenderá a se verificar mais nos cursos de mestrado profissional do que naqueles acadêmicos, puxados por grupos empresariais do ensino privado. Os doutorados ainda serão uma realidade 'distante da distância'.

Uma segunda questão: o perfil dos estudantes da pós-graduação stricto sensu sofrerá alterações? A tendência é de que o público-alvo dos cursos de pós-graduação stricto sensu a distância seja formado pelos estudantes com faixa etária superior à indicada por Schwartzman (2010), ao referir-se à média de 34 anos de idade dos estudantes dos cursos presenciais lato sensu e stricto sensu, ou, mais especificamente, por aqueles citados por Colombo (2018). Assim, a faixa etária superior a 34 anos se coaduna com a idade dos nossos entrevistados, que cursaram a pós-graduação stricto sensu em países do Mercosul. Ademais, os estudantes oriundos da cultura da graduação a distância em instituições de ensino superior públicas e privadas, somados aos servidores públicos e àquele público do mercado, que demandam qualificação, formarão a base da pós-graduação stricto sensu a distância.

Com a expansão gradual da pós-graduação stricto sensu a distância no Brasil, principalmente no mestrado profissional, os ritos de reconhecimento de diplomas estrangeiros não sofrerão alteração. Na esteira dessa expansão, cogitamos que não tardará a regulamentação pelo MEC de cursos stricto sensu semipresenciais, para além da existência pontual de editais específicos e de experiências com programas de formação híbrida da Capes em instituições de educação superior para os mestrados profissionais (CAPES, 2018), incluindo aquelas em períodos intensivo (MEC, [2013]). Assim, tendencialmente, poderá haver: a ampliação da oferta semipresencial de mestrado profissional por instituições públicas e privadas, à semelhança do formato existente em países do Mercosul; a sua redução; ou ainda nenhuma oferta de mestrados acadêmicos ou doutorados.

A oferta de cursos de mestrado e doutorado stricto sensu na modalidade educacional a distância diminuirá a busca de cursos em outros países do Mercosul? Sobre essa terceira questão, a tendência é que continue a haver busca por cursos stricto sensu em países do Mercosul. Isso tende a ocorrer porque as instituições educacionais privadas terão maior oferta e, como verificado em nossa pesquisa, no Brasil, o valor para realizar um curso de pós-graduação em uma instituição privada é muito superior ao valor cobrado em países vizinhos, além dos processos seletivos brasileiros serem mais rigorosos. A longo prazo, quando e se existir, ao contrário das demandas de instituições privadas, a oferta de cursos de mestrado

11 Embora não seja a centralidade do nosso artigo, a Portaria Capes nº 90/2019 suscita questões e tendências a serem verificadas por pesquisas futuras. 
ou doutorado a distância pelas IES públicas tendem a se revestir de um caráter experimental, com poucas vagas. Esses motivos continuarão a influenciar a opção dos estudantes por pósgraduações stricto sensu em outros países do Mercosul, principalmente por parte daqueles que moram em cidades do interior do Brasil, como sete dos oito entrevistados.

Outras questões se somam a essas, a saber: o perfil dos professores-orientadores de mestrado e doutorado a distância será alterado em comparação ao perfil dos docentes do ensino presencial? A internacionalização da educação superior ganhará impulso com a pós-graduação a distância? Essas são problematizações para pesquisas futuras.

Fatores políticos, materiais, culturais e sociais, entre outros, formam o espaço social concreto de compreensão dos riscos, das potencialidades e dos conflitos na oferta da $\mathrm{EaD}$, envolvendo um conjunto de sujeitos (SOUSA, 2014). Esses aspectos também podem ser estendidos ao formato semipresencial ou híbrido na pós-graduação stricto sensu, mas identificamos que as especificidades do modelo, como o tempo de alternância entre momentos presenciais e a distância durante os processos formativos, não dispensam a rigorosidade metódica dessa formação, no que diz respeito à importância de experiências cotidianas de produção do conhecimento por parte do estudante trabalhador no ou a partir do chão da instituição formadora, em situações como: os estágios docentes, as monitorias presenciais, as experiências em laboratórios, os projetos de pesquisa, que se articulam ao ensino e à extensão, as reuniões presenciais, as interações em sala, entre outras iniciativas.

Em alusão ao estudante trabalhador que busca a pós-graduação stricto sensu, independentemente da modalidade (presencial, semipresencial ou EaD), enfatizamos a atualidade do pensamento de Bourdieu (2001, p. 264):

[...] as esperanças tendem universalmente a se harmonizar mais ou menos às oportunidades objetivas. [...] Essa lei de tendência das condutas humanas, fazendo com que a esperança subjetiva de ganho tenda a se conformar à probabilidade objetiva de ganho, comanda a propensão para investir (dinheiro, trabalho, tempo, afetividade) nos diferentes campos. (BOURDIEU, 2001, p. 264).

O perfil dos estudantes que buscaram a pós-graduação stricto sensu em países do Mercosul revela, em suas trajetórias, traços da íntima relação entre a desigualdade social e a desigualdade cultural no Brasil. Os estudantes, em sua maioria, oriundos de famílias pouco abastadas, não herdaram da família o capital cultural e econômico necessário ao investimento futuro em pós-graduações no exterior, mas, ao longo das suas jornadas no serviço público, com o passar do tempo, puderam constituir um capital para o investimento. Portanto, em suas trajetórias em direção à pós-graduação stricto sensu, eles foram ajustando as probabilidades subjetivas e objetivas de ganho em função da conversão do capital cultural em capital econômico.

\section{REFERÊNCIAS}

ALCÂNTARA, Manoela; BERNARDES, Adriana. Universidade [UnB] pede à Polícia Federal que investigue pelo menos cinco casos de fraude. Professores de três estados entregaram certificados de cursos de mestrado e doutorado de outros países com validação da 
instituição brasiliense - o que nunca ocorreu. Correio Braziliense, Brasília, DF, Caderno Cidades, p. 17, 17 jun. 2015.

AVALIAÇÃO da Capes aponta crescimento da pós-graduação brasileira. Fundação Capes, Brasília, 19 set. 2017. Disponível em: https://bit.ly/3wPaQ0n. Acesso em: 20 jun. 2020.

BOURDIEU, Pierre. Les trois états du capital culturel. Paris: Actes de la recherche em sciences sociales, 1979.

BOURDIEU, Pierre. La distinción: Criterio y bases sociales del gusto. Madrid: Taurus, 1982.

BOURDIEU, Pierre. Razões práticas: sobre a teoria da ação. Campinas: Papirus, 1996.

BOURDIEU, Pierre. Meditações Pascalianas. Rio de Janeiro: Bertrand Brasil, 2001.

BOURDIEU, Pierre. A produção da crença: contribuição para uma economia dos bens simbólicos. São Paulo: Zouk, 2002.

BOURDIEU, Pierre. A economia das trocas simbólicas. São Paulo: Perspectiva, 2007.

BOURDIEU, Pierre. A miséria do mundo. Petrópolis: Vozes, 2008.

BOURDIEU, Pierre; PASSERON, Jean-Claude. A reprodução. Rio de Janeiro: Francisco Alves, 1992.

BOURDIEU, Pierre; CHAMBOREDON, Jean-Claude; PASSERON, Jean-Claude. A profissão de sociólogo: preliminares epistemológicas. Petrópolis, RJ: Vozes, 1999.

BRASIL. Ministério da Educação. Conselho Nacional de Educação. Câmara de Educação Superior. Resolução n. 3, de 22 de junho de 2016. Dispõe sobre normas referentes à revalidação de diplomas de cursos de graduação e ao reconhecimento de diplomas de pós-graduação stricto sensu (mestrado e doutorado), expedidos por estabelecimentos estrangeiros de ensino superior. Diário Oficial da União: Brasília, DF, Edição 119, Seção 1, p. 923 jun. 2016. Disponível em: . Acesso em: 20 mar. 2021.

BRASIL. Ministério da Educação. Inscrições para mestrado em matemática vão até 5 de julho. Brasília: MEC, [2013]. Disponível em: https://bit.ly/2OJGew2. Acesso em: 20 mar. 2021.

BRITO, Angela Xavier. Trajetória. In: CATANI, Afrânio Mendes; NOGUEIRA, Maria Alice; HEY, Ana Paula; MEDEIROS, Cristina Carta Cardoso (org.). O Vocabulário Bourdieu. Belo Horizonte: Autêntica, 2017. p. 354-356.

CASTRO, Priscilla Campos de. Trajetórias de estudantes no jogo escolar pela busca e reconhecimento de diplomas stricto sensu semipresencial de países do Mercosul. 2019. 
Dissertação (Mestrado em Educação) - Faculdade de Educação, Universidade de Brasília, Brasília, 2019.

COORDENAÇÃO DE APERFEIÇOAMENTO DE PESSOAL DE NÍVEL SUPERIOR (BRASIL). Reconhecimento de títulos de pós-graduação obtidos no exterior. Assessoria de Imprensa da Capes, Brasília, [200-]. Disponível em: https://bit.ly/3tg1kBb. Acesso em: 20 mar. 2021.

COORDENAÇÃO DE APERFEIÇOAMENTO DE PESSOAL DE NÍVEL SUPERIOR (BRASIL). Portaria $\mathrm{n}^{\mathrm{o}} 2.117$, de 6 de dezembro de 2019a. Dispõe sobre a oferta de carga horária na modalidade de ensino a distância - EaD em cursos de graduação presenciais ofertados por instituições de educação superior - IES pertencentes ao sistema federal de ensino. Diário Oficial da União: Brasília, DF, Edição 239, Seção 1, p. 131, 11 dez. 2019. Disponível em: https://bit.ly/3d7M0kD. Acesso em: 20 mar. 2021.

COORDENAÇÃO DE APERFEIÇOAMENTO DE PESSOAL DE NÍVEL SUPERIOR (BRASIL). Portaria n $\mathrm{n}^{\circ}$ 90, de 24 de abril de 2019b. Dispõe sobre os programas de pós-graduação stricto sensu na modalidade de educação a distância. Diário Oficial da União: Brasília, DF, Edição 80, Seção 1, p. 45, 26 abr. 2019. Disponível em: https://bit.ly/3uKcuOY. Acesso em: 20 mar. 2021.

CATANI, Afrânio Mendes; NOGUEIRA, Maria Alice; HEY, Ana Paula; MEDEIROS, Cristina Carta Cardoso (org.). O Vocabulário Bourdieu. Belo Horizonte: Autêntica, 2017.

COLOMBO, Daniel Gama e. A desigualdade no acesso à pós-graduação stricto sensu brasileira: análise do perfil dos ingressantes de cursos de mestrado e doutorado. In: BOF, Alvana Maria; OLIVEIRA, Adolfo Samuel de (org.). Cadernos de Estudos e Pesquisas em Políticas Educacionais Anísio Teixeira, Brasília, 2018. v. 1, p. 241-274.

GRENFELL, Michael. Interesse. In: GRENFELL, Michael. Pierre Bourdieu: conceitos fundamentais. Petrópolis: Vozes, 2018. p. 199-220.

INSTITUTO NACIONAL DE ESTUDOS E PESQUISAS EDUCACIONAIS ANÍSIO TEIXEIRA. Censo da Educação Superior 2019: notas estatísticas. Brasília: INEP, [ca 2020]. Disponível em: https://bit.ly/32fixyZ. Acesso em: 13 abr. 2021.

JOURDAIN, Anne; NAULIN, Sidonie. A teoria de Pierre Bourdieu e seus usos sociológicos. Petrópolis: Vozes, 2017.

LEBARON, Francis. Capital. In: CATANI, Afrânio Mendes; NOGUEIRA, Maria Alice; HEY, Ana Paula; MEDEIROS, Cristina Carta Cardoso (org.). O Vocabulário Bourdieu. Belo Horizonte: Autêntica, 2017. p. 101-103.

MATON, Karl. Habitus. In: GRENFELL, Michael. Pierre Bourdieu: conceitos fundamentais. Petrópolis, RJ: Vozes, 2018. p. 73-94. 
MAZZUOLI, Valério de Oliveira. A questão do reconhecimento de títulos de mestrado e doutorado provenientes dos países do Mercosul. Scientia Iuris, Londrina, v. 15, n. 1, p. 9-28, jun. 2011. Disponível em: https://bit.ly/3takM2g. Acesso em: 20 set. 2020.

MONTAGNER, Miguel Ângelo. Trajetórias e biografias: notas para uma análise bourdieusiana. Sociologias, Porto Alegre, n. 17, p. 240-264, jun. 2007. Disponível em: https://bit. ly/3tdBDBg. Acesso em: 20 set. 2020.

NICHELE, Brigida; COSTA, Danilo de Melo; PRÉVE, Altamiro Damian. Aspectos do reconhecimento de diplomas estrangeiros: um estudo na UFSC. In: COLÓQUIO INTERNACIONAL SOBRE GESTÃO UNIVERSITÁRIA NA AMÉRICA DO SUL, 9. 2009, Florianópolis. Anais [...]. Florianópolis: UFSC, 2019. p. 1-14. Disponível em: https://bit. ly/326DtYT. Acesso em: 20 set. 2020.

PLATAFORMA Carolina Bori. Sistema Nacional de Revalidação e Reconhecimento de Diplomas. Sistema informatizado criado pelo Ministério da Educação (SESu e CAPES), para gestão e controle de processos de Revalidação e Reconhecimento de diplomas estrangeiros no Brasil. Brasília, 2021. Disponível em: https://bit.ly/3dXYmep . Acesso em: 20 mar. 2021.

SAINT MARTIN, Monique de. Capital Social. In: CATANI, Afrânio Mendes; NOGUEIRA, Maria Alice; HEY, Ana Paula; MEDEIROS, Cristina Carta Cardoso (org.). O Vocabulário Bourdieu. Belo Horizonte: Autêntica, 2017. p. 113-117.

SCHWARTZMAN, Simon. Nota sobre a transição necessária da Pós-Graduação brasileira. In: BRASIL. Plano Nacional de Pós-Graduação - PNPG 2011- 2020. Brasília: Capes, 2010. p. 34-52. Disponível em: https://bit.ly/2PODiPy. Acesso: 20 maio 2020.

SOUSA, Carlos Alberto Lopes de Sousa. A pesquisa no ensinar e aprender em e no entorno dos ambientes conectados virtualmente e presencialmente: riscos e potencialidades. In: FERNANDES, Maria Lídia Bueno; DECONTO, Neuza Maria; LOPES, Ruth Gonçalves de Faria (org.). Tessituras e tramas: refletindo sobre a experiência da licenciatura em Pedagogia a distância na FE/UnB. Brasília: Editora da UnB, 2014. p. 175-200.

THOMSON, Patrícia. Campo. In: GRENFELL, Michael. Pierre Bourdieu: conceitos fundamentais. Petrópolis: Vozes, 2018. p. 95-114.

TRIVIÑOS, Augusto Nibaldo Silva. Introdução à pesquisa em ciências sociais: pesquisa qualitativa em educação. São Paulo: Atlas, 1987.

UNIVERSIDADE DE BRASÍLIA (UnB). Revalidação e reconhecimento de diploma estrangeiro - RRDE. Brasília, 2014. Disponível em: https://bit.ly/3wXezcz. Acesso em: 29 mar. 2020. 
VILARINHO, Lucia Regina; GONZALEZ, Wania Regina Coutinho. Diplomas de mestrado e doutorado em Educação obtidos em universidades estrangeiras: o reconhecimento a partir da concretude dos dados. Revista Brasileira de Pós-Graduação, Santa Cruz do Sul, RS, v. 11, n. 26, 9 dez. 2014. Disponível em: https://bit.ly/3dW3vn5. Acesso em: 20 set. 2020.

\section{DADOS DOS AUTORES}

\section{Priscilla Campos de Castro}

Mestra em Educação. Servidora pública da Universidade de Brasília (UnB), Brasília/DF, Brasil.priscillacastro@unb.br

\section{Carlos Lopes}

Doutor em Sociologia. Professor Associado da Universidade de Brasília (UnB), atua na graduação e no Programa de Pós-Graduação em Educação da Faculdade de Educação, Brasília/DF, Brasil. carloslopes@unb.br

Submetido em: 31-08-2020

Aceito em: 25-05-2021 